\title{
Perceptions of Political Comuption and Voting Behavior in South Korea
}

\author{
EUNJUNG CHOI*
}

\begin{abstract}
While regular and competitive elections are expected to lower political corruption by holding elected officials accountable for their actions, citizens often fail to vote corrupt officials out of office in elections. This article explores how citizens' perceptions of political corruption influence their voting behavior by testing three competing theories: nonvoting, opposition voting, and corruption voting. This study also investigates the types of voters involved in each form of voting by considering three mediating factors: economic evaluation, partisanship, and education. Empirical findings from the South Korean case suggest that, in general, the high level of perceived corruption decreases voter turnout, confirming the nonvoting theory. Second, corruption voting occurs mostly among those who positively evaluate the economy and have the same partisan affiliation as the incumbent candidate. Finally, a high level of education leads to opposition voting. In sum, the empirical evidence confirms that incumbent candidates' and party's political corruption does not always lead to the electoral victory of opposition parties and their candidates because the mediating factors play a role in strengthening or weakening the patterns of nonvoting, opposition voting, and corruption voting.
\end{abstract}

Keywords: political corruption, voting, democracy, South Korea

* Associate Professor, Chonnam National University, South Korea;

E-mail: ejchoi76@jnu.ac.kr

DOI: 10.16934/isr.20.2.201912.1 


\section{INTRODUCTION}

Political corruption, broadly defined as the "misuse of public office for private gain," has numerous detrimental effects on society. Political corruption causes maladministration and wastes public resources for private interests, thus, retarding a country's economic growth and widening the gap between the haves and have-nots (Nye 1967; Kaufman 1997; Mauro 1995; Chea 2015; Johnson et al. 2011; Theobald 1990; You and Khagram 2005; Elliot 1997). Furthermore, corruption seriously weakens the core values of democracy, such as accountability, equality, and openness (Dahl 1971; Anderson and Tverdova 2003; O'Donnell 1994). Ultimately, corruption undermines social and political trust, weakens citizens' beliefs in democratic norms and values, and strengthens their willingness to accept non-democratic political alternatives (Mishler and Rose 2005; Manzetti and Wilson 2006; 2007; Chang and Chu 2006; Della Porta and Vannucci 1999; Uslaner 2008; 2013; Pharr 2000). In particular, political corruption hinders new democracies' march toward democratic consolidation (Canache and Allison 2005; Shedler et al. 1999).

A rich body of literature on corruption suggests that democracy reduces a country's level of political corruption through its "self-correcting" mechanisms (Gerring and Thacker 2004; Montinola and Jackman 2002; Sandholtz and Koetzle 2000; Shleifer and Vishny 1993; Tavits 2007; Mungiu-Pippidi 2013). In particular, free, fair, and competitive elections are expected to vote corrupt politicians out of office. As such, if citizens are able to identify corrupt politicians, they will utilize the electoral process to punish them. However, a plethora of work also reveals an uneasy fact that elections often do not function, or are not effective enough to punish corrupt incumbents (McCann and Dominguez 1998; Choi and Woo 2010; Seligson 2002; Davis et al. 2004; Powell and Whitten 1993; Powell 2000; Tavits 2007; Manzetti and Wilson 2007; Fackler and Lin 1995; Peters and Welch 1980). Often, elections in a democracy, falls short of functioning as a strong-enough deterrent against political corruption.

Why do electoral mechanisms often fail to vote corrupt candidates out of office? Does this happen because citizens do not have enough knowledge and information about corruption, becomes tired of corrupt politics, and decide not to vote, or vote for a corrupt candidate precisely because (s)he is corrupt? Regarding the perception of corruption and individual voting behavior, three theoretical arguments have been offered: opposition voting theory, nonvoting theory, and corruption voting theory. Opposition voting theory suggests that citizens withdraw their support for a corrupt candidate and vote for the opposition candidate. Here, what matters is how strong the opposition voting is. Meanwhile, nonvoting theory argues that electoral politics fail to punish corrupt politicians because citizens decide not to vote when they believe that politics overall is corrupt. Nonvoting 
behavior simply lowers citizens' political participation; thus, opposition candidates fail to mobilize enough support to win. Finally, corruption voting theory maintains that citizens vote for a corrupt candidate with the expectation that (s)he will reward them with certain material benefits. Corruption voting occurs because voters believe that the overall material benefits from the corrupt candidate will outweigh the cost of electing the incumbent.

While extensive scholarly research presents conflicting evidence regarding the perception of corruption and voting behavior, it does not further elaborate when and why different voting patterns- nonvoting, opposition voting, and corruption voting-occur. As a result, empirical evidence on corruption and voting behavior remains inconclusive because no studies comprehensively test the competing arguments. The main contribution of this article is to gauge the relative influence of political corruption in elections and the main determinants thereof. This article suggests that three mediating factors ${ }^{-}$partisanship, evaluation of the economy, and level of education-shape the perception of political corruption and its varying effects on individual voting decisions. It is argued that these mediating factors are responsible for the failure of democratic elections to deter political corruption.

The study empirically tests the above-mentioned theories of corruption and voting in South Korea, which is often praised as an exemplary case of democratic consolidation and economic development alongside rampant political corruption. After more than three decades of democratic experience, South Korea remains plagued with numerous political corruption scandals and the punishment of corrupt politicians and business owners. The empirical analysis in this article reveals that, in South Korea, the high level of perceived corruption leads to nonvoting rather than opposition voting. Moreover, citizens' partisan affiliations and their evaluations of the economy mediate their perceptions of corruption and voting decisions. Shared partisanship with the incumbent party candidate and a positive evaluation of the economy lead to corruption voting, while opposition partisanship and a higher level of education strengthen opposition voting. Meanwhile, although a higher level of education results in opposition voting, it is not strong enough to determine an electoral outcome.

The following section discusses the issue of political corruption in post-democratization South Korea. Section two introduces three competing theories regarding political corruption and individual voting behavior, from which competing hypotheses are generated for the empirical analysis. Sections three and four present the research design and empirical analysis. The article concludes with a discussion on the theoretical implications of the empirical findings and suggestions for future research on political corruption and voting behavior. 


\section{CORRUPTION AND POLITICS IN SOUTH KOREA}

Ample empirical work on political corruption confirms the corruptionreducing effects of democracy and the free market economy, as most democratic regimes with an open economic structure record much lower levels of perceived corruption than non-democracies (Canache and Allison 2005; Gerring and Thacker 2004; Montinola and Jackman 2003; Sandholtz and Koetzle 2000; Seligson 2002; Tavits 2007; Treisman 2000). In particular, the institutional design of democracy (e.g., separation of powers, checks and balances, elections, free media, and public opinion) functions as an effective deterrent against political corruption, which thrives in secrecy. Moreover, the accompanying norms of democracy such as fairness, rule of law, and accountability are expected to activate citizens' willingness to detect, publish, and punish corrupt politicians. Democracy transforms ordinary individuals from passive subjects to enlightened citizens to fight against corruption (Lindstedt and Naurin 2010).

Contrary to such expectations, however, post-democratization politics in South Korea have witnessed numerous scandals and the prosecution of politicians and business leaders for their corrupt transactions. Despite more than three decades of democratic trials, South Korea has remained unsuccessful in curbing corruption, and ordinary citizens express strong views that their society is highly corrupt. Mass protests in 2016, in which more than 17 million people cumulatively participated, led to the impeachment of the previous president, Park Geun-hye. President Park was impeached by Parliament in December 2016, and this was confirmed by the Constitutional Court of Korea three months later. Subsequently, she was arrested on 18 cases of corruption charges including bribery, extortion, abuse of power, and leaking secret state information. Moreover, her presidential predecessor Lee Myung-bak (2008-2013) and several of his political aides and family members face numerous corruption charges. The ongoing investigation of previous governments' unlawful and corrupt records reveals the painful truth that political corruption is inherent in the "system" in democratic South Korea (Harris 2017).

Some scholars connect political corruption in South Korea to its culture, suggesting that a "culture of corruption" exists in the country in which the practice of gift-giving as "a means of showing respect and confirming a reciprocal relationship" is essentially tantamount to bribery (Quah 2011, 321; Oh 1999, 165). East Asian countries in general and South Korea in particular are considered hard cases for the study of corruption because of their miraculous economic growth amid excessive corruption, which has created the term the "Asian paradox" (Chang and Chu 2006, 261). While political corruption has had various negative impacts on countries from different continents, it has played a "developmental" role in the economic growth of East Asian countries. Based on 
this positive role of political corruption in the East Asian context, several scholars concluded that Confucian values as the defining characteristic of Asian culture are not compatible with Western liberal political norms and value systems and foster the culture of corruption (Lipset and Lenz 2000; Park and Shin 2006; Shin 2011; Huntington 1991; Pye 2006; Fukuyama 1995; Morlino, Bressel, and Pelizzon 2011). Furthermore, based on Confucian cultural legacies and developmental corruption, individuals in South Korea may "regard corruption as an acceptable practice" and view it "as wholly neutral without raising any negative attitude toward political institutions" and corrupt political elites (Chang and Chu 2006, 262).

While Park Jung-hee's state-led industrialization since the 1960s brought about miraculous economic growth in South Korea, it also created a system of political corruption in the nexus between politics and business. Kang's comparative study of political corruption in South Korea and the Philippines illustrates how cronyism and clientelism as forms of corruption created a "mutual hostages" situation between politics and business to lower transaction costs and enhance economic growth (Kang 2002; 2003). The mutual hostages condition makes both parties vulnerable to each other; thus, they share a strong incentive to collude. Corruption enables "better information about the actors, easier monitoring and enforcing of agreements, greater confidence in exchange, and more ease in making side payments and engaging in reciprocity" (Kang 2003, 443). Park Jung-hee's government-led economic policies provided a small number of chaebols with preferential benefits in the form of policy loans and tax breaks at the expense of other small businesses, blue-collar workers, and farmers. With favoritism and other benefits from the government, a small number of big businesses in South Korea became highly competitive in the international market and the engine for economic growth. At the same time, however, such unbalanced economic development enabled chaebols to dominate the entire national economy and build a deeply entrenched system of political corruption.

Park Jung-hee has been a divisive figure in the post-democratization politics of South Korea. Critics of Park remember him as a brutal military dictator who brazenly suppressed political freedom and democracy and created massive economic inequality and political corruption. However, those who have positive memories of the previous dictator remember his role in boosting national security and economic growth. An interesting trend after the 1997 Asian financial crisis was that a majority of South Korean citizens came to view Park's leadership in an increasingly positive manner. Park's popularity grew when the Kim Young-sam government (1993-1998) mismanaged the economy, resulting in an economic crisis that caused the first negative economic growth since the 1979 oil shock. The rise of Park Jung-hee's popularity after the 1997 financial crisis is evident from the results of multiple public opinion polls. A Gallup poll conducted during 
the 1997 crisis revealed that approximately 80 percent of respondents positively evaluated Park Jung-hee's leadership and his performance. In another Gallup poll conducted in 2015, 93.3 percent of respondents positively evaluated his contribution to the country's economic development (Kang 2010; Gallup Korea 2015). In these polls, Park recorded higher popularity than any other democratically elected presidents since the 1987 presidential election. Moreover, the so-called Park Jung-hee syndrome gave rise to the electoral victories of conservative political parties in the 2007 and 2012 presidential elections, in which Lee Myung-bak (2008-2013) and Park Geun-hye (2013-2017) won by mobilizing public nostalgia for Park. The rising popularity of Park Jung-hee seems to suggest that many South Koreans consider economic matters more important than other issues such as political freedom, rule of law, and political corruption.

The case of South Korea presents unique challenges to the study of political corruption because of its successful democratization and consolidation alongside a high level of corruption. In its three decades of democratic experience, South Korean politics have had four power alternations between the conservatives and progressives, each lasting approximately 10 years. However, such regular power alternations through competitive elections have not lowered the level of perceived political corruption in the country. For instance, Transparency International's Corruption Perceptions Index (CPI) ranked South Korea $40^{\text {th }}$ out of 158 countries surveyed in $2005,39^{\text {th }}$ out of 178 countries in 2010, and $45^{\text {th }}$ out of 180 countries in 2018 (Transparency International 2019). South Korea has not improved its CPI rankings but remains more corrupt than many other peer countries that experienced democratic transition in roughly the same period.

The continuing political corruption in South Korea generates intriguing questions. Are the citizens of South Korea not bothered by corrupt politicians, and why do they continue to vote for them? Presumably, individuals might support corrupt candidates because they benefit in some way from corruption. Alternatively, do they "throw the rascals out" and vote for an opposition candidate? Citizens might want to vote out the corrupt candidates, but punishment is not often effective enough to deter corrupt politicians.

\section{POLITICAL CORRUPTION AND VOTING: THREE THEORIES}

Regarding the puzzle on the perception of corruption and individual voting, a predominant body of literature focuses on institutional-level factors such as constitutional arrangements, the level of (de)centralization of power, political party systems, and electoral rules and campaign laws (Tavits 2007; Kunicova and 
Rose-Ackerman 2005; Gingerich 2013; Yadav 2011; Mistree 2015; Gerring and Thacker 2004). These works argue that complex institutional structures and political procedures blur the responsibility for political corruption among parties and individual politicians. The lack of clarity of responsibility or voters' inability to identify corrupt parties and candidates means that electoral politics often fail to vote corrupt politicians out of office. Despite a rich body of literature on the political institutional factors of corruption and electoral outcomes, comprehensive tests of competing theories on corruption and voting at the individual level are relatively scant. This section introduces three individual-level theories about corruption and voting and generates hypotheses for empirical testing.

\section{Opposition Voting Theory}

Presumably, the most commonsense expectation should be that citizens vote for the opposition candidate when they believe that the incumbent candidate/ party is highly corrupt. One of the defining characteristics of democracy is to make elected officials accountable to their electorates. Politicians as agents are expected to work for their constituents as principals, and the principals decide whether they continue to keep their agents for the next term. Since the elected officials' primary interest is reelection, they will work hard to receive their constituents' support. Political corruption can be viewed as a performance issue like other issues, e.g., economic performance, management of national security, and honesty and fairness in the provision of public goods in society. Furthermore, political corruption has been blamed as a major source of poor political performance, which leads to electoral defeat.

Previous empirical research reveals that citizens' perceptions of corruption lower their trust in the government, form negative evaluations of political systems, and weaken their belief in regime legitimacy (Anderson and Tverdova 2003; Seligson 2002; Chang and Chu 2006). The question is whether the perceptions of political corruption lead to opposition voting that is strong and effective enough to unseat the corrupt incumbent. Some scholars investigate the association between corruption scandals and congressional elections in the United States, finding that corruption scandals lower voters' support for a candidate by 5 - 10 percent (Peters and Welch 1980; Welch and Hibbing 1997; Jacobson and Dimmock 1994; Basinger 2013; Praino et al. 2013). Similarly, a study by Ferraz and Finan (2008) reveals that a corrupt candidate loses approximately 10 percent of support in mayoral elections in Brazil. Furthermore, Reed's analysis (1996) on electoral outcomes in Japan since the 1940s shows that 62 percent of lawmakers with corruption charges are reelected. Although corruption scandals and citizens' perceptions of corruption are different, both have been found to negatively affect the incumbents' gains in elections. Overall, empirical evidence has demonstrated 
the negative effect of the perception of corruption on the election of corrupt candidates.

However, the question is whether that amount of loss is enough to change the electoral outcome. Likely, certain factors mediate or weaken opposition voting. For instance, voters' partisan affiliations may mediate the association between corruption perception and voting behavior. Party identification as a perceptual screen is known to shape individual attitudes toward political issues, including corruption and political figures (Anderson and Tverdova 2003; Bartels 2002; Blais et al. 2010; Campbell et al. 1960; Jerit and Barabas 2012; Seligson 2002; Tverdova 2011). Therefore, those who are attached to the incumbent and his/her party may care much less about political corruption and will continue to support the incumbent (party) in the next election. On the other hand, opposition partisans have a harsher evaluation about incumbent's political corruption, thus, are involved in opposition voting more than their counterparts. Ultimately, for opposition voting to occur, voters should have an alternative party (or parties) to choose from, which is not possible in a one-party dominant system. In South Korea, although multiple parties exist, only two major parties have chances to acquire a ruling status. For South Korean voters to choose opposition voting, they should cross the partisan line to choose the opposition party/candidate.

Another mediating factor is the incumbent's performance, which is commonly measured by economic performance. The evaluations of different areas of government performance influence each other because individuals try to maintain cognitive consistency (Saris and Sniderman 2004). In particular, considering the importance of economic issues to South Koreans, economic evaluations conditions the effect of corruption perception on vote choice. Voters may continue to support a highly corrupt incumbent candidate if the incumbent's economic performance is positively evaluated (Tverdova 2011; Klasnja and Tucker 2013; Manzetti and Wilson 2007; Zechmeister and Zizumbo-Colunga 2013). In contrast, if the incumbent's economic performance is negative, then citizens will blame political corruption for the poor performance and vote the incumbent out of office. Finally, citizens' levels of education may mediate opposition voting. Inferred from clarity of responsibility literature, those highly educated or informed have a better understanding about institutional complexity and identify the person to be blamed for political corruption better than those less educated and poorly informed; thus, the former is more likely to be involved in opposition voting. Recent empirical studies find a negative effect of information about corruption on incumbent vote share (Chang, Golden, and Hill 2010; Chong et al. 2015; Peter and Welch 1980; Winters and Weitz-Shapiro 2013). 
From the opposition voting theory, we generate the following hypotheses:

Hypothesis 1: Individuals are more likely to withdraw their support for the incumbent party candidate and vote for the opposition candidate when they have a high level of perception about political corruption.

Hypothesis 1-1: Individuals are more likely to choose opposition voting when they share partisanship with the opposition candidate.

Hypothesis 1-2: Individuals are more likely to choose opposition voting when their level of education is relatively high.

Hypothesis 1-3: Individuals are more likely to choose opposition voting when they negatively evaluate the incumbent's economic performance.

\section{Nonvoting Theory}

For opposition voting to become strong enough to defeat corrupt incumbents, individual voters should be able and willing to punish them in the elections. However, as mentioned earlier, individuals may have their own reasons for not unseating the corrupt incumbent due to (a) partisan affiliation, (b) the corrupt incumbent's performance, or (c) lack of political knowledge. Alternatively, citizens may fail to unseat corrupt politicians because they decide not to participate in elections. Nonvoting theory contends that electorates fail to unseat corrupt incumbents because they do not bother to vote, and a low voter turnout does not provide opposition candidates with opportunities to mobilize dissatisfied voters. If this holds true, there must be a strong negative correlation between the level of perceived corruption and voter turnout.

McCann and Dominguez's (1998) study on political corruption and elections in Mexico corroborates the nonvoting theory. The authors confirm that "perceptions of electoral fraud and corruption had no significant impact on the likelihood of voting for the opposition" (McCann and Dominguez 1998, 498). They demonstrate that, in the Mexican elections, voters who support opposition candidates have a much lower turnout because they remain skeptical about the efficacy of their votes. Chong et al. (2015) also confirm the connection between corruption and nonvoting in Mexican elections. Similarly, Davis et al. (2004) present the same finding through a comparative analysis of corruption perception and electoral outcomes in three Latin American countries. In Costa Rica, Mexico, and Chile, "a greater awareness of political corruption $\cdots$ does not necessarily lead to opposition voting. Rather $\cdots$ it leads to withdrawal from the electoral arena $\cdots$ There is a certain irony here in that opposition parties may ultimately hurt themselves by exposing political corruption or by making an issue of it" (Davis et 
al. 2004, 700). The empirical finding in regard to the perception of corruption and nonvoting has been confirmed by the cases from post-communist countries as well as cross-national/regional studies (Kostadinova 2009; Stockemer, LaMontagne, and Scruggs 2013).

Why do voters decide not to participate in elections when they perceive high levels of political corruption? One possible answer is that citizens' perceptions of corruption often do not differentiate between individual candidates or parties. Thus, when they hear about corruption scandals, they tend to believe that the entire political system (including both incumbents and opposition candidates) is corrupt. Therefore, information about corruption scandals significantly weakens voters' beliefs about the efficacy of their votes. In their experimental study, Chong and his colleagues (2014) find that information about incumbent corruption hurts both incumbent and opposition parties by decreasing electoral turnout. A high level of corruption perception may transform citizens from active participants to passive subjects. Alternatively, nonvoting may occur due to individual voters' lack of information about politics in general and political corruption in particular. Political information or awareness is known to increase political participation in general by reducing the cost of political involvement (Delli Capini and Keeter 1996; Larcinese 2007; Popkin and Dimock 1999; Fazio 1986; Wang 2015; Wattenberg et al. 2000). A lack of information about corruption makes the clarity of responsibility obscure, so that potential opposition voters abstain, as they do not know who to vote for, or are frustrated (Peters and Welch 1980; Taylor 2000; Tillman 2008; Winters nd Weitz-Shapiro 2013). Moreover, partisan affiliation may also lead to nonvoting. When there is a high level of perceived corruption, the incumbent party/candidate supporters may decide not to vote for the incumbent and do not cross the partisan line to support the opposition party/candidate. While the relationship between economic conditions and political participation is inconclusive (Blais 2006; Weschle 2014), the incumbent supporters' nonvoting tendency may be stronger when their evaluation about the economy is negative. As mentioned above, negative evaluation of the economy weakens voters' support for the incumbent candidate/party, thereby lowering voter turnout. However, the negative economic evaluation is oftentimes not strong enough to make voters cross the partisan line for opposition voting.

As was the case for the opposition voting theory, it is expected that three intervening factors ${ }^{-}$partisanship, education, and economic performance- ${ }^{-}$will affect an individual's decision for nonvoting. From the nonvoting theory, we generate the following hypotheses:

Hypothesis 2: Individuals decide not to participate in elections, rather than punish corrupt candidates, when they have a high 
level of perception about political corruption.

Hypothesis 2-1: Individuals are more likely to choose nonvoting when they share partisanship with the corrupt incumbent party candidate.

Hypothesis 2-2: Individuals are more likely to choose nonvoting when they have a low level of education.

Hypothesis 2-3: Individuals are more likely to choose nonvoting when they negatively evaluate the incumbent's economic performance.

\section{Corruption Voting Theory}

Both the opposition and nonvoting theories suggest that electorates often fail to unseat corrupt incumbents from power because of the weak support for opposition candidates or a lack of political participation. One intriguing aspect is that corrupt incumbents sometimes garner more popular support in elections. Why do voters continue to support the corrupt candidate? Numerous empirical studies provide empirical evidence regarding the electoral successes of corrupt incumbents across countries (Choi and Woo 2010; Zechmeister and ZizumboColunga 2013; Manzetti and Wilson 2006; 2007; Klanja and Tucker 2013; Bauhr and Charron 2018). Corruption voting theory suggests that electorates continue to support corrupt incumbents despite (and often because of) a candidate's undue corruption in the expectation that the corrupt candidate will continue to provide them with material benefits.

Corruption voting theory focuses on the way public goods are distributed in a country that has weak or ill-functioning political institutions. For instance, Manzetti and Wilson (2007) suggest that political elites and electorates are connected through a clientelist network in which the leaders becomes patrons and citizens as their clients. When formal political institutions are unable to deliver public goods to society, the cliental network replaces the institutional channels to distribute them to clients. When patron-client networks replace official institutional channels, citizens as clients continue to support the corrupt incumbents as long as the latter are able to deliver material benefits to the former. Chang and Kerr (2017) apply the insider ${ }^{-}$outsider theory of political corruption and voting in 18 sub-Saharan African countries. They find that individuals are tolerant of corrupt politicians when the former and the latter form clientelist networks through partisan or ethnic ties. In their embedded survey experiment conducted in Brazil, Winters and Weitz-Shapiro (2013, 420) confirm the trade-off hypothesis, which contends that "voters knowingly elect corrupt politicians when those politicians provide voters with other benefits."

Corruption voting theory argues that citizens are willing to accept the loss 
of public resources if corrupt politicians can deliver public goods such as jobs, local construction projects, and economic growth. Moreover, although citizens are aware of the extent of political corruption in society, other political issues may be their priority, such as poverty and inequality, national security, natural disasters, and so on. Therefore, other electoral issues often trump the corruption issue, and voters end up supporting corrupt candidates if the former believe that the latter are better at managing these important issues (Choi and Woo 2010). For empirical analysis about corruption voting, this article utilizes voters' evaluation of the national economic conditions as a proxy measure of corruption voting. It assumes that, if the national economy is in good shape, citizens continue to support the corrupt incumbent party/candidate with the expectation that the incumbent will continue to maintain good economic performance.

Similar to the previous two theories, the three mediating factors also influence corruption voting. First, voters' partisanship can either strengthen or weaken corruption voting. Incumbent supporters will choose corruption voting, while a higher level of perceived corruption will strengthen the opposition or nonvoting tendencies among opposition supporters. Second, voters' evaluation of the economic performance of the incumbent candidate/party may affect corruption voting. If they evaluate the economy positively, then corruption voting will be more prominent. However, a negative evaluation of the economy will weaken corruption voting. Finally, voters' level of education also mediates corruption voting. Individuals with a lower level of education are more susceptible to corruption voting than those with a higher level of education.

From the corruption voting theory, we generate the following hypotheses:

Hypothesis 3: Individuals are more likely to continue to support the corrupt incumbent party candidate when they are satisfied with the incumbent's performance while in office.

Hypothesis 3-1: Individuals are more likely to choose corruption voting when they share partisanship with the incumbent party candidate.

Hypothesis 3-2: Individuals are more likely to choose corruption voting when they have a low level of education.

Hypothesis 3-3: Individuals are more likely to choose corruption voting when they believe national economic conditions improved while the incumbent was in office.

\section{DATA AND MEASEREMENTS}

This study uses the Asian Barometer Survey (ABS, $4^{\text {th }}$ Wave) to examine 
the relationship between the perception of corruption and individual voting behavior in South Korea. Since the survey was conducted from October through December 2015, the questions regarding voter turnout and vote choice pertains to the 2012 presidential election. While other public opinion surveys ask about how widespread political corruption is in the country of interest, the ABS questions the degree of political corruption in both the national and local governments. The question allows respondents to pay particular attention to political corruption in the current government rather than in politics as a whole. In other words, by separating incumbents' political corruption from that of the opposition or system, the measure makes it possible to test the corruption voting argument that individuals support the corrupt incumbent or their party candidate in the subsequent election.

\section{Variables}

The dependent variables are voter turnout and voting choice, as the main purpose of the current study is to identify the effects of political corruption on individuals' decision - nonvoting, opposition voting, or corruption voting. The ABS asks whether a respondent voted in the 2012 presidential election and which candidate (s)he voted for. Respondents who voted are coded as 1 and, otherwise, 0 . In the vote choice model, the dependent variable has three categories: 0 for nonvoters, 1 for Park Geun-hye voters, and 2 for Moon Jae-in voters. Nonvoting hypothesis is tested by using a binary logistic model while corruption- and opposition-voting hypotheses, by using a multinomial logistic model.

Next, we test the effects of the mediating variables, i.e., economic conditions, party identification, and education, by dividing the sample into two groups: one for individuals with a high corruption perception and the other for those with a low corruption perception. The turnout and corruption/opposition voting models include the perception of political corruption, all the mediating variables, and other demographic factors such as gender, subjective class identification, and age, which are commonly considered determinants of voting behavior. The mediating models use the same predictors as the first one, except for the perception of corruption, because each model analyzes the sample with the same level of corruption perception. As addressed above, the corruption perception variable is measured with the pervasiveness of corruption and bribe-taking in the national government on a 4-point scale from "Hardly anyone is involved" to "Almost everyone is corrupt." In measuring partisanship, the ABS asks which party a respondent feels closest to by providing a list that includes the ruling "Saenuri Party," the largest opposition "the New Politics Alliance for Democracy" (NPAD), and a minor opposition "Justice Party." Based on the question, we create three dummy variables of partisanship: the ruling (Saenuri 
party identifiers), the opposition partisans (the NPAD and Justice Party identifiers), and the independent. Although the Justice Party is a little more left than the NPAD, both share several common ideologies, as many members in that party are from the Uri Party, an antecedent party of the NPAD. Evaluation of the changes in national economic conditions ranges from much worse (1) to much better (5).

This study uses education as a proxy of political information or knowledge. Education is known to be one of the strongest predictors of the level of political information/knowledge, political involvement, interest in politics, etc. (Delli Carpini and Keeter 1996; Rasmussen 2015). In other words, education indicates not only "what" individuals know about politics but also "how much and how a person thinks about politics" (Luskin 1987, 864). Political information, knowledge, and sophistication are different concepts but are used interchangeably and have similar consequences on individual political behavior. Although named and defined differently, one of the most common measures of political knowledge has been the number of factual items answered correctly (Converse 2000; Delli Carpini and Keeter 1996; Lau and Redlawsk 1997; Price and Zaller 1993; Zaller 1992). However, factual questions test the ability to recall rather than understanding; moreover, the correct answers for the list of factual items say little about the quality or ability of political decisions with weak validity (Gordon and Segura 1997; Lupia 2006; Lupia and McCubbins 1998; Luskin 1987). Not only does the ABS not include factual political knowledge items, but also education is a better indicator of how much individuals think about and understand politics.

\section{TABLE 1. CORRUPTION PERCEPTION BY POLITICAL, ECONOMIC, AND} DEMOGRAPHIC FACTORS

\begin{tabular}{|c|c|c|c|c|c|c|c|c|}
\hline & & \multicolumn{4}{|c|}{ Comuption Perception } & \multirow[b]{2}{*}{$\begin{array}{c}\text { Average } \\
\text { (Std.) }\end{array}$} & \multirow[b]{2}{*}{ total } & \multirow[b]{2}{*}{ Chi2/F } \\
\hline & & $\begin{array}{c}\text { Hardly } \\
\text { anyone } \\
(\%)\end{array}$ & $\begin{array}{c}\text { Not many } \\
\text { officials } \\
(\%)\end{array}$ & $\begin{array}{c}\text { Most } \\
\text { officials } \\
\text { (\%) }\end{array}$ & $\begin{array}{c}\text { Almost } \\
\text { everyone } \\
(\%)\end{array}$ & & & \\
\hline \multirow{3}{*}{ Vote Choice } & Non-voters & $\begin{array}{c}4 \\
(2.38)\end{array}$ & $\begin{array}{c}63 \\
(37.50)\end{array}$ & $\begin{array}{c}81 \\
(48.21)\end{array}$ & $\begin{array}{c}20 \\
(11.90)\end{array}$ & $\begin{array}{l}1.696 \\
(.707)\end{array}$ & 168 & \multirow{3}{*}{$\begin{array}{c}29.52^{* * *} \\
9.81^{* * *}\end{array}$} \\
\hline & $\begin{array}{c}\text { Park } \\
\text { Guen-hye }\end{array}$ & $\begin{array}{c}6 \\
(1.22)\end{array}$ & $\begin{array}{c}276 \\
(56.33)\end{array}$ & $\begin{array}{c}181 \\
(36.94)\end{array}$ & $\begin{array}{c}27 \\
(5.51)\end{array}$ & $\begin{array}{l}1.467 \\
(.620)\end{array}$ & 490 & \\
\hline & Moon Jae-in & $\begin{array}{c}3 \\
(1.03)\end{array}$ & $\begin{array}{c}125 \\
(43.10)\end{array}$ & $\begin{array}{c}144 \\
(49.66)\end{array}$ & $\begin{array}{c}18 \\
(6.21)\end{array}$ & $\begin{array}{l}1.613 \\
(.617)\end{array}$ & 290 & \\
\hline \multirow{3}{*}{$\begin{array}{c}\text { Party } \\
\text { Identification }\end{array}$} & Ruling & $\begin{array}{c}5 \\
(1.36)\end{array}$ & $\begin{array}{c}219 \\
(59.51)\end{array}$ & $\begin{array}{c}128 \\
(34.78)\end{array}$ & $\begin{array}{c}16 \\
(4.35)\end{array}$ & $\begin{array}{l}1.421 \\
(.599)\end{array}$ & 368 & \multirow{3}{*}{$\begin{array}{l}34.57^{* * *} \\
11.07^{* * *}\end{array}$} \\
\hline & Opposition & $\begin{array}{c}1 \\
(.57)\end{array}$ & $\begin{array}{c}83 \\
(47.43)\end{array}$ & $\begin{array}{c}77 \\
(44.00)\end{array}$ & $\begin{array}{c}14 \\
(8.00)\end{array}$ & $\begin{array}{l}1.594 \\
(.644)\end{array}$ & 175 & \\
\hline & Independent & $\begin{array}{c}17 \\
(2.66)\end{array}$ & $\begin{array}{c}265 \\
(42.41)\end{array}$ & $\begin{array}{c}304 \\
(47.50)\end{array}$ & $\begin{array}{c}54 \\
(8.44)\end{array}$ & $\begin{array}{l}1.617 \\
(.677)\end{array}$ & 640 & \\
\hline
\end{tabular}




\begin{tabular}{|c|c|c|c|c|c|c|c|c|}
\hline & & \multicolumn{4}{|c|}{ Corruption Perception } & \multirow[b]{2}{*}{$\begin{array}{l}\text { Average } \\
\text { (Std.) }\end{array}$} & \multirow[b]{2}{*}{ total } & \multirow[b]{2}{*}{ Chi2/F } \\
\hline & & $\begin{array}{c}\text { Hardly } \\
\text { anyone } \\
(\%)\end{array}$ & $\begin{array}{c}\text { Not many } \\
\text { officials } \\
\text { (\%) }\end{array}$ & $\begin{array}{c}\text { Most } \\
\text { officials } \\
(\%)\end{array}$ & $\begin{array}{c}\text { Almost } \\
\text { everyone } \\
(\%)\end{array}$ & & & \\
\hline \multirow{3}{*}{$\begin{array}{l}\text { National } \\
\text { Economic } \\
\text { conditions }\end{array}$} & $\begin{array}{c}\text { Very } \\
\text { bad/bad }\end{array}$ & $\begin{array}{c}10 \\
(1.28)\end{array}$ & $\begin{array}{c}344 \\
(44.16)\end{array}$ & $\begin{array}{c}359 \\
(46.08)\end{array}$ & $\begin{array}{c}66 \\
(8.47)\end{array}$ & $\begin{array}{l}1.617 \\
(.657)\end{array}$ & 779 & \multirow{3}{*}{$\begin{array}{l}25.59^{* * *} \\
11.06^{* * *}\end{array}$} \\
\hline & $\begin{array}{l}\text { Not good } \\
\text { nor bad }\end{array}$ & $\begin{array}{c}12 \\
(3.54)\end{array}$ & $\begin{array}{c}186 \\
(54.87)\end{array}$ & $\begin{array}{c}127 \\
(37.46)\end{array}$ & $\begin{array}{c}14 \\
(4.13)\end{array}$ & $\begin{array}{l}1.422 \\
(.631)\end{array}$ & 339 & \\
\hline & $\begin{array}{c}\text { Good/ } \\
\text { very good }\end{array}$ & $\begin{array}{c}0 \\
(0.00)\end{array}$ & $\begin{array}{c}35 \\
(57.38) \\
\end{array}$ & $\begin{array}{c}22 \\
(36.07)\end{array}$ & $\begin{array}{c}4 \\
(6.56)\end{array}$ & $\begin{array}{l}1.492 \\
(.622)\end{array}$ & 61 & \\
\hline \multirow[b]{2}{*}{ Education } & $\begin{array}{c}\sim \text { Complete } \\
\text { secondary/hi } \\
\text { gh school }\end{array}$ & $\begin{array}{c}15 \\
(2.19)\end{array}$ & $\begin{array}{c}255 \\
(48.98)\end{array}$ & $\begin{array}{c}294 \\
(42.98)\end{array}$ & $\begin{array}{c}40 \\
(5.85)\end{array}$ & $\begin{array}{l}1.525 \\
(.641)\end{array}$ & 684 & \multirow{2}{*}{$\begin{array}{l}.215 / \\
2.97^{*}\end{array}$} \\
\hline & $\begin{array}{c}\text { Some } \\
\text { university } \\
\text { education \& } \\
\text { above }\end{array}$ & $\begin{array}{c}8 \\
(1.60)\end{array}$ & $\begin{array}{c}232 \\
(46.49)\end{array}$ & $\begin{array}{c}215 \\
(43.09)\end{array}$ & $\begin{array}{c}44 \\
(8.92)\end{array}$ & $\begin{array}{l}1.591 \\
(.672)\end{array}$ & 499 & \\
\hline
\end{tabular}

Source: The author's computation

Note: ${ }^{*} p \leq .1{ }^{* *} p \leq .05^{* * *} p \leq .01$

Table 1 presents the correlational analysis between the perception of corruption and the mediating factors as well as the dependent variable. First, regarding the relationship between vote choice and corruption perception, nonvoters and Moon Jae-in (i.e., opposition) voters mostly chose "Most officials are corrupt," while Park Geun-hye (i.e., incumbent) voters mostly reported, "Not many officials are corrupt." The ANOVA results also demonstrate that the difference in the average corruption perceptions of nonvoters and Moon Jae-in voters is not statistically significant, but the average corruption perception among Park Geun-hye supporters is significantly different from (or lower than) that of the other two groups. Second, the relationship between party identification and corruption perception is similar to the relationship between corruption perception and vote choice. That is, opposition party identifiers and independents have a similar corruption perception, while ruling party identifiers have a lower level of perceived corruption than the other groups. Although a correlational result, this suggests that party identification as a perceptual screen influences the ways that individuals perceive the extent of political corruption in the national government.

Third, individuals with a poor evaluation of national economic conditions seem to have a higher corruption perception than those who assess the economy as "neither good nor bad." Among those who positively evaluated economic conditions, their perception of corruption did not substantially differ from that of the other two groups. However, the comparison between the positive evaluators and the others should be cautious because the sample size of the former is too small. Finally, high school graduates and those with a higher level of education 
share a similar perception of political corruption. Both groups mostly chose the category, "Not many officials are corrupt," followed by "Most officials are corrupt." In short, stronger and clearer associations of party affiliation and economic conditions with the perception of corruption indicate that they mediate the effects of corruption perception on electoral behavior (nonvoting, corruption voting, or opposition voting), while the level of education does little. Because the results are based only on correlational evidence, further analysis that controls for other relevant variables is presented in the following section.

\section{TABLE 2. VOTER TURNOUT AND VOTE CHOICE IN THE 2012 PRESIDENTIAL ELECTION}

\begin{tabular}{|c|c|c|c|c|}
\hline & \multirow{2}{*}{$\begin{array}{c}\text { Logistic Regression } \\
\text { Estimates } \\
\text { (Std. Error) } \\
\text { Turnout } \\
\end{array}$} & \multicolumn{3}{|c|}{$\begin{array}{l}\text { Multinomial Logistic Regression Estimates } \\
\text { (Std. Error) }\end{array}$} \\
\hline & & $\begin{array}{l}\text { Vote for Park/ } \\
\text { Nonvoting }\end{array}$ & $\begin{array}{l}\text { Vote for Moon/ } \\
\text { Nonvoting }\end{array}$ & $\begin{array}{c}\text { Vote for Moon/ } \\
\text { Vote for Park }\end{array}$ \\
\hline $\begin{array}{l}\text { Corruption } \\
\text { perception }\end{array}$ & $\begin{array}{l}-.255^{*} \\
(.139)\end{array}$ & $\begin{array}{l}-.350^{* *} \\
(.168)\end{array}$ & $\begin{array}{l}-.199 \\
(.174)\end{array}$ & $\begin{array}{l}.151 \\
(.164)\end{array}$ \\
\hline $\begin{array}{l}\text { Economic } \\
\text { conditions }\end{array}$ & $\begin{array}{l}.219^{*} \\
(.127)\end{array}$ & $\begin{array}{l}.308^{* *} \\
(.146)\end{array}$ & $\begin{array}{l}.067 \\
(.154)\end{array}$ & $\begin{array}{l}-.241^{*} \\
(.145)\end{array}$ \\
\hline Ruling party & $\begin{array}{l}1.086^{* * *} \\
(.278)\end{array}$ & $\begin{array}{l}1.967^{* * *} \\
(.289)\end{array}$ & $\begin{array}{l}-.981^{* *} \\
(.433)\end{array}$ & $\begin{array}{l}-2.948^{* * *} \\
(.353)\end{array}$ \\
\hline Opposition party & $\begin{array}{l}.518^{* *} \\
(.262)\end{array}$ & $\begin{array}{l}-1.532^{* * *} \\
(.448)\end{array}$ & $\begin{array}{l}1.769^{* * *} \\
(.282)\end{array}$ & $\begin{array}{l}3.300^{* * *} \\
(.395)\end{array}$ \\
\hline Education & $\begin{array}{l}.179^{* *} \\
(.078) \\
\end{array}$ & $\begin{array}{l}.011 \\
(.089) \\
\end{array}$ & $\begin{array}{l}.326 \\
(.093)\end{array}$ & $\begin{array}{l}.315^{* * *} \\
(.083)\end{array}$ \\
\hline Gender $($ male $=1)$ & $\begin{array}{l}.121 \\
(.185) \\
\end{array}$ & $\begin{array}{l}.025 \\
(.221)\end{array}$ & $\begin{array}{l}.033 \\
(.228) \\
\end{array}$ & $\begin{array}{l}.008 \\
(.215)\end{array}$ \\
\hline Class & $\begin{array}{l}.103 \\
(.066)\end{array}$ & $\begin{array}{l}.133^{*} \\
(.079)\end{array}$ & $\begin{array}{l}.086 \\
(.081)\end{array}$ & $\begin{array}{l}-.047 \\
(.078)\end{array}$ \\
\hline $20 \mathrm{~s}$ & $\begin{array}{l}-2.850^{* * *} \\
(.414)\end{array}$ & $\begin{array}{l}-2.806^{* * *} \\
(.471)\end{array}$ & $\begin{array}{l}-3.133^{* * *} \\
(.492)\end{array}$ & $\begin{array}{l}-.328 \\
(.433)\end{array}$ \\
\hline $30 \mathrm{~s}$ & $\begin{array}{l}-1.755^{* * *} \\
(.421)\end{array}$ & $\begin{array}{l}-1.484^{* * *} \\
(.460)\end{array}$ & $\begin{array}{l}-2.038^{* * *} \\
(.485)\end{array}$ & $\begin{array}{l}. .554 \\
(.391)\end{array}$ \\
\hline $40 \mathrm{~s}$ & $\begin{array}{l}-1.158^{* * *} \\
(.400)\end{array}$ & $\begin{array}{l}-.971^{* *} \\
(.431) \\
\end{array}$ & $\begin{array}{l}-1.349^{* * *} \\
(.456) \\
\end{array}$ & $\begin{array}{l}-.377 \\
(.352) \\
\end{array}$ \\
\hline $50 \mathrm{~s}$ & $\begin{array}{l}-.443 \\
(.422)\end{array}$ & $\begin{array}{l}-.082 \\
(.451)\end{array}$ & $\begin{array}{l}-.778 \\
(.481)\end{array}$ & $\begin{array}{l}-.695^{* *} \\
(.355)\end{array}$ \\
\hline Constant & $\begin{array}{l}1.013^{*} \\
(.613)\end{array}$ & $\begin{array}{l}.969 \\
(.691) \\
\end{array}$ & $\begin{array}{l}-1.039 \\
(.772) \\
\end{array}$ & $\begin{array}{l}-2.008^{* * *} \\
(.689)\end{array}$ \\
\hline Pseudo $\mathrm{R}^{2}$ & $.163^{* * *}$ & & $.341^{* * *}$ & \\
\hline $\mathrm{N}$ & 1127 & & 907 & \\
\hline
\end{tabular}

Source: Regression results

Note: ${ }^{*} p \leq .1{ }^{* *} p \leq .05^{* * *} p \leq .01$ 


\section{EMPIRICAL ANALYSIS}

Table 2 shows how corruption perception and other relevant factors influence individuals' electoral behavior. The results of the turnout model demonstrate that the higher an individual's corruption perception, the less likely (s)he is likely to vote, confirming the nonvoting hypothesis. Individuals who think that hardly anyone is corrupt are 67.5 percent more likely to vote than those who perceive that almost everyone is corrupt. Economic conditions have a positive effect on voter turnout: Individuals with the highest evaluation of economic conditions are 73.5 percent more likely to vote than those who have a low evaluation. As expected, partisans-both ruling and opposition party identifiers - are three times and 1.7 times more likely to participate in elections than independents, respectively. As ruling party supporters are more likely to vote than opposition party affiliates, the status quo is maintained, and the corrupt incumbent kept in power. Furthermore, a higher level of education increases the odds of voting by 1.2 times. Gender does not make much difference, while age influences individuals' decision to vote: The younger age groups, other than those in their 50s, are less likely to vote than the oldest group (60 years and older). Overall, the turnout model seems to support the nonvoting hypothesis that corrupt incumbents tend to remain in power because voters abstain from voting rather than vote against them.

The multinomial logistic regression analyzes how corruption perception affects individual decisions on nonvoting, opposition voting, or corruption (incumbent) voting. The results provide further evidence for the nonvoting hypothesis. Individuals choose not to vote rather than vote for the ruling party candidate Park Geun-hye when they have a higher corruption perception. For example, if corruption perception increases from most officials to almost everyone, individuals are 30 percent less likely to vote than to vote for Park Geun-hye. However, corruption perception does not make much difference in the choices between voting for the opposition party candidate Moon Jae-in and nonvoting, and between voting for Moon and voting for Park. The varying effects of corruption across different choice contexts can be attributed to the fact that corruption as a performance issue is considered more as a systemic problem than as a specific administration's problem. A better economic evaluation helps the ruling party by increasing the probability of voting for Park rather than abstaining or voting for Moon. Economic conditions, another performance issue, influence electoral decisions involving the incumbent party candidate only. The effects of party identification are consistent with the expectation that party identifiers are more likely to vote for their own party candidate, but they abstain when they have to choose between nonvoting and another party's candidate. The odds of voting for Park and Moon against nonvoting among each party's identifiers are 7.2 times 
and 5.9 times that of the independents, respectively. A higher education level provides Moon with an advantage: those with a higher level of education are more likely to vote for Moon than abstain or vote for Park. In short, the results in Table 2 suggest that (1) voters with a higher level of corruption perception abstain rather than vote for the opposition and (2) ruling party identifiers are more likely to vote than their counterparts, which prevents corrupt incumbents from being ousted.

TABLE 3. THE EFFECTS OF MEDIATING FACTORS BY CORRUPTION PERCEPTION

\begin{tabular}{ccccccc}
\hline & \multicolumn{5}{c}{ Multinomial Logistic Regression Odds Ratio } \\
(Std. Error)
\end{tabular}

Source: Regression results

Note: ${ }^{*} p \leq .1^{* *} p \leq .05^{* * *} p \leq .01$

Then, what are the mediating effects of economic conditions, party affiliation, and education between corruption perception and electoral behavior? By grouping the sample into two - one for high corruption perceivers who believe that most or almost all officials are corrupt and the other for low corruption perceivers who think that only a few officials are corrupt, Table 3 presents the effects of the mediating factors on each group.

First, considering the effect of economic conditions in both groups, the more positively a person evaluates the economy, the more likely (s)he is to vote for the incumbent party candidate than to abstain. Compared with individuals who rate the economy as good, those who assess it as very good are around 1.4 times more likely to vote for Park than not vote. This suggests that voters overlook the issue of corruption when the economy is in good condition, thus supporting the corruption voting hypothesis. Furthermore, similar to the results for the whole sample, those who perceive low corruption consider economic conditions in choosing between Park and Moon, while high corruption perceivers do not. This suggests that the economy and political corruption as performance 
issues compete to influence the elections and that economic issues become more salient in evaluating the incumbent party candidate in a low corruption context.

Second, regarding the effect of party identification, individuals affiliated with the ruling party continue to support its candidate despite regarding the government as being corrupt. Compared with independents, they are eight and 26 times more likely to vote for Park than abstain or vote for Moon, respectively. The ruling partisanship is a weaker predictor of individual voting behavior among low corruption perceivers. As such, ruling party affiliates with a high corruption perception have a 26 times higher likelihood of voting for Park than for Moon, while those with a low corruption perception have a 13 times greater chance of voting for Park than for Moon. In addition, ruling party affiliates with high corruption perception abstain rather than vote for Moon, while ruling party identification is not a significant factor in the choice of low corruption perceivers. This also implies that partisan allegiance contributes to corruption voting. Contrary to the effect of ruling party identification, opposition partisanship has a much stronger effect on low corruption perceivers than on those with high corruption perception. For the former group, compared with independents, opposition partisans are around eight times more likely to abstain than to vote for Park and about seven and 53 times more likely to vote for Moon than abstain and vote for Park, respectively. Among the latter, the odd ratios are smaller: Opposition partisanship triples the probability of abstaining against voting for Park and increases the likelihood of voting for Moon against nonvoting and voting for Park by six and 19 times, respectively. As discussed, opposition supporters become less enthusiastic about electoral participation when they perceive that political corruption is a systemic problem and not that of a particular party or administration. These results explain why a corrupt party or candidate continues to prevail.

Finally, education has a different effect than the other two mediating factors. In both groups, a higher level of education promotes opposition voting. Having a higher education increases the odds of voting for Moon against either abstaining or voting for Park by $1.3^{-1.5}$ times. Education is not a significant factor in the choice between Park and nonvoting in both groups. These outcomes indicate that economic conditions and ruling party allegiance lead to corruption voting, while education deters it. The more educated or informed consider corruption information in both high and low corruption contexts and vote against the incumbent party candidate. In short, the outcomes imply that people tend to abstain from voting when they think political corruption is pervasive in the government. Party identification and education, as mediating factors between corruption perception and electoral behavior, function more consistently than do economic conditions. On the one hand, the effects of party identification and education are stronger among those with a higher corruption perception than 
among their counterparts. Individuals close to the ruling party are involved in corruption voting, while those highly educated choose opposition voting. On the other hand, economic conditions only partially support corruption voting. Individuals with a positive evaluation of economic performance are involved more in corruption voting than in nonvoting, but there is no clear evidence of corruption voting against opposition voting. Rather, economic conditions have more significant effects on the electoral behavior of those who perceive lower corruption.

\section{CONCLUSION}

This article addresses the limited utility of democratic electoral processes in reducing political corruption. In other words, the study considers why regular and competitive elections are not strong enough to deter political corruption. It tests three hypotheses - nonvoting, opposition voting, and corruption votingregarding the perception of corruption and individual voting behavior. The empirical analysis investigates how three intervening factors - partisan affiliation, evaluation of the economy, and the level of education-mediate the perception of corruption and voting. The study tests the competing hypotheses against the case of South Korea, a country that has achieved democratic consolidation and economic development amid an unusually high level of political corruption compared with other relatively new democracies.

In general, the empirical analysis supports the nonvoting, not the opposition voting, hypothesis, demonstrating that a high level of perceived corruption significantly decreases individuals' participation in elections. However, partisans do not abstain but are more likely to vote for their own party candidate, regardless of their corruption perception. Moreover, corruption voting is confirmed among those who positively evaluate the incumbent government's performance in the economy and share a partisan affiliation with the ruling candidate. However, when voters believe that political corruption is pervasive, a positive evaluation of the economy does not uniformly lead to corruption voting. Economic evaluations are important only in the choice between Park and nonvoting, and not between Park and Moon. One interesting finding is that ruling partisanship has a much stronger effect in a highly corrupt context than in a less corrupt one, while the opposite is true for opposition partisanship. This suggests that corrupt incumbents or their parties continue to win because the ruling partisanship encourages corruption voting, while opposition partisans are mobilized less when corruption perception is high. Finally, a high level of education leads to opposition voting, and its effect is similar in both high and low corruption contexts. In sum, the empirical evidence illustrates that political corruption does not lead to the electoral victory of opposition candidates and their 
parties because mediating factors play a role in strengthening or weakening the patterns of nonvoting, opposition voting, and corruption voting differently.

What does the empirical analysis say about the future study of political corruption and elections in democratic regimes? Because the "perception" definition of political corruption is adopted in this article, which may not be identical with corruption itself, future research on this subject should clarify what determines the perception of corruption and how different sources of corruption perception affect individual voting decisions. This perception may be shaped through individuals' direct experiences with, or indirect observations of, corruption, or it might be based on unproven rumors, politically motivated charges, or citizens' dissatisfaction with the way government performs. It may be more fruitful for future research to clarify the origins of the perceptions of corruption and analyze how different perceptions affect individual voting behavior. Furthermore, the relationship between corruption and electoral outcomes ultimately hinges on the political strategies and abilities of opposition parties and candidates to mobilize the corruption issue for their electoral victory. As this study illustrates, nonvoting is more prominent than opposition voting, which means that opposition forces often fail to take advantage of the corruption problem for electoral success. Upcoming research may go further to identify institutional contexts and campaign strategies for opposition forces to gain electoral victory.

\section{REFERENCES}

Anderson, Christopher J., and Yuliya V. Tverdova. 2003. "Corruption, Political Allegiances, and Attitudes toward Government in Contemporary Democracies." American Journal of Political Science 47(1): 91-109.

Basinger, Scott J. 2013. "Scandals and Congressional Elections in the PostWatergate Era." Political Research Quarterly 66(2): 385-398.

Bartels, Larry M.. 2002. "Beyond the Running Tally: Partisan Bias in Political Perceptions." Political Behavior 24(2): 117-150.

Bauhr, Monika, and Nicholas Charron. 2018. "Insider or Outsider? Grand Corruption and Electoral Accountability." Comparative Political Studies 51(4): 415-446

Blais, Andre, Elisabeth Gidengil, and Anja Kilibarda. 2017. "Partisanship, Information, and Perceptions of Government Corruption." International Journal of Public Opinion Research 29(1): 95-110.

Campbell, Angus, Philip E. Converse, Warren E. Miller, and Donald E. Stokes. 1960. The American Voter. Chicago: Chicago University Press.

Canache, Damarys, and Michael E. Allison. 2005. "Perceptions of Corruption in 
Latin American Democracies." Latin American Politics and Society 47: 91-111.

Chang, Eric C., Miriam A. Golden, and Seth Hill. 2010. "Legislative Malfeasance and Political Accountability." World Politics 62(2): 177-220.

Chang, Eric C., and Yun-han Chu. 2006. "Corruption and Trust: Exceptionalism in Asian Democracies?” Journal of Politics 68(2): 259-271.

Chang, Eric C., and Nicholas N. Kerr. 2017. "An Insider-Outsider Theory of Popular Tolerance for Corrupt Politicians." Governance: An International Journal of Policy, Administration, and Institutions 30(1): 67-84.

Chea, Chiam Chooi. 2015. "Empirical Studies: Corruption and Economic Growth." American Journal of Economics 5(2): 183-188.

Choi, Eunjung, and Jongseok Woo. 2010. "Political Corruption, Economic Performance, and Electoral Outcomes: A Cross-National Analysis." Contemporary Politics 16(3): 249-262.

Chong, Alberto, Ana L. De La O, Dean Karlan, and Leonard Wantchekon. 2015. "Does Corruption Information Inspire the Fight or Quash the Hope? A Field Experiment in Mexico on Voter Turnout, Choice, and Party Identification." The Journal of Politics 77(1): 55-71.

Converse, Philip E.. 2000. "Assessing the Capacity of Mass Electorates." Annual Review of Political Science 3: 331-353

Dahl, Robert A. 1971. Polyarchy: Participation and Opposition. New Haven: Yale University Press.

Davis, Charles L., Roderic Ai Camp, and Kenneth M. Coleman. 2004. "The Influence of Party Systems of Citizens' Perceptions of Corruption and Electoral Response in Latin America." Comparative Political Studies 37(6): 677-703.

Della Porta, Donatella, and Alberto Vannucci. 1999. Corrupt Exchanges: Actors, Resources, and Mechanisms of Political Corruption. New York: Aldine de Gruyter.

Delli Carpini, Michael. X., and Scott Keeter. 1996. What Americans Know about Politics and Why it Matters. New Haven, CT: Yale University Press.

Elliot, Kimberly A. 1997. Corruption, Capitalism, and Democracy. Washington DC: Institute for International Economics.

Fackler, Tim, and Tse-min Lin. 1995. "Political Corruption and Presidential Elections, 1929-1992." Journal of Politics 57(4): 971-993.

Fazio, Russell. 1986. "How Do Attitudes Guide Behavior?" In Handbook of Motivation and Cognition: Foundations of Social Behavior edited by Richard M. Sorrentino and Edward T. Higgins, 200-243. New York, NY: Guilford Press.

Ferraz, Claudio, and Frederico Finan. 2008. "Exposing Corrupt Politicians: The Effects of Brazil's Publicly Released Audits on Electoral Outcomes." 
Quarterly Journal of Economics 123(2): 703-745.

Fukuyama, Francis. 2015. "Confucianism and Democracy." Journal of Democracy 6(2): 20-33.

Gallup Korea. 2015 Gallup Korea Daily Opinion. A http://gallupkorea.blogspot. ca/2015/08/1742015-8-1.html.

Gerring, John, and Strom C. Thacker. 2004. "Political Institutions and Corruption: The Role of the Unitarism and Parliamentarism." British Journal of Political Science 34(2): 295-330.

Gingerich, Daniel W. 2013. Political Institutions and Party-Directed Corruption in South America: Stealing for the Team. New York: Cambridge University Press.

Gordon, Stacy B., and Gary M. Segura. 1997. "Cross-National Variation in the Political Sophistication of individuals: Capability or Choice?" The Journal of Politics 59(1): 126-147.

Harris, Peter. 2017. "South Korea's Sweeping Anti-Corruption Divides the Country." Financial Times, November 20, 2017. Accessed https://www. ft.com/content/ec3a6810-cda9-11e7-b781-794ce08b24dc.

Huntington, Samuel P. 1991. The Third Wave: Democratization in the Late Twentieth Century. Norman: University of Oklahoma Press.

Jacobson, Gary, and Michael Dimock. 1994. "Checking Out: The Effects of Bank Overdraft on the 1992 House Elections." American Journal of Political Science 38(3): 601-624.

Jerit, Jennifer, and Jason Barabas. 2012. "Partisan Perceptual Bias and the Information Environment." The Journal of Politics 74(3): 672-84.

Johnson, Noel D., Courtney L. LaFountain, and Steven Yamarik. 2011. "Corruption Is Bad for Growth (even in the United States)." Public Choice 147(3): 377-393

Kang, David. 2002. Crony Capitalism: Corruption and Development in South Korea and the Philippines. New York: Cambridge University Press. . 2003. "Transaction Costs and Crony Capitalism in East Asia." Comparative Politics 35(4): 439-58.

Kang, Won-Taek. 2010. "Missing the Dictator in a New Democracy: Analyzing the "Park Chung Hee Syndrome" in South Korea." Political and Military Sociology: An Annual Review 38(1): 1-25.

Kaufman, Daniel. 1997. “Corruption: The Facts.” Foreign Policy 107: 114-131. Klasnja, Marko, and Joshua A. Tucker. 2013. "The Economy, Corruption, and the Vote: Evidence from Experiments in Sweden and Moldova." Electoral Studies 32(3): 536-543.

Kostadinova, Tatiana. 2009. "Abstain or Rebel: Corruption Perceptions and Voting in East European Elections." Politics \& Policy 37(4): 691-714.

Kunicova, Jana, and Susan Rose-Ackerman. 2005. "Electoral Rules and 
Constitutional Structures as Constraints on Corruption.” British Journal of Political Science 35(4): 573-606.

Larcinese, Valentino. 2007. "Does Political Knowledge Increase Turnout? Evidence from the 1997 British General Election.” Public Choice 131(3): 387-411.

Lau, Richard R., and David P. Redlawsk. 1997. "Voting Correctly." The American Political Science Review 91(3): 585-598.

Lindstedt, Catharina, and Daniel Naurin. 2010. "Transparency Is Not Enough: Making Transparency Effective in Reducing Corruption." International Political Science Review 31(3): 301-22.

Lipset, Seymour M., and Gabriel Salman Lenz. 2000. "Corruption, Culture, and Markets." In Culture Matters, edited by Lawrence E. Harrison and Samuel P. Huntington, 112-124. New York: Basic Books.

Lupia, Arthur. 2006. "How Elitism Undermines the Study of Voter Competence." Critical Review 18: 217-232.

Lupia, Arthur, and Mathew D. McCubbins. 1998. The Democratic Dilemma: Can Citizens Learn What They Really Need to Know? New York: Cambridge University Press.

Luskin, Robert C. 1987. "Measuring Political Sophistication." American Journal of Political Science 31(4): 856-899.

Manzetti, Luigi, and Carole J. Wilson. 2006. "Corruption, Economic Satisfaction, and Confidence in Government: Evidence from Argentina." The Latin Americanist 49(2): 131-139.

Manzetti, Luigi, and Carole J. Wilson. 2007. "Why do Corrupt Governments Maintain Support?" Comparative Political Studies 40(8): 949-970.

Mauro, Paolo. 1995. "Corruption and Growth." Quarterly Journal of Economics 110(3): 681-712.

McCann, James A., and Jorge I. Dominguez. 1998. "Mexicans React to Electoral Fraud and Political Corruption: An Assessment of Public Opinion and Voting Behavior." Electoral Studies 17(4): 483-504.

Mishler, William, and Richard Rose. 2005. "What Are the Political Consequences of Trust? A Test of Cultural and Institutional Theories in Russia." Comparative Political Studies 38(9): 1050-1078.

Mistree, Dinsha. 2015. "Party-Directed Corruption in the Developing World." Comparative Politics 47(3): 354-374.

Montinola, Gabriella R., and Robert W. Jackman. 2002. "Sources of Corruption: A Cross-Country Study." British Journal of Political Science 32(1): 147-170.

Morlino, Leonardo, Bjorn Dressel, and Riccardo Pelizzo. 2011. "The quality of democracy in Asia-Pacific: issues and findings." International Political Science Review 32(5): 491-511. 
Mungiu-Pippidi, Alina. 2013. "Becoming Denmark: Historical Designs of Corruption Control." Social Research 80(4): 1259-1286.

Nye, Joseph S. 1967. "Corruption and Political Development: A Cost-Benefit Analysis." American Political Science Review 61(2): 417-427.

O’Donnell, Guillermo. 1994. "Delegative Democracy." Journal of Democracy 5: 55-69.

Oh, John Kie-Chiang. 1999. Korean Politics: The Quest for Democratization and Economic Development. Ithaca: Cornell University Press.

Park, Chong-Min, and Doh Chull Shin. 2006. "Do Asian Values Deter Popular Support for Democracy in South Korea?" Asian Survey 46(3): 341-361.

Peters, John, and Susan Welch. 1980. "The Effects of Charges of Corruption on Voting Behavior in Congressional Elections." American Political Science Review 74(3): 697-708.

Pharr, Susan J. 2000. "Officials' Misconduct and Public Distrust: Japan and the Trilateral Democracies." In Disaffected Democracies: What's Troubling the Trilateral Countries? edited by Susan J. Pharr and Robert D. Putnam, 173-201. Princeton, NJ: Princeton University Press.

Popkin, Samuel L., and Michael A. Dimock. 1999. "Political Knowledge and Citizen Competence." In Citizen Competence and Democratic Institutions edited by Stephen. L. Elkin and Karol E. Soltan, 117-146. University Park, PA: Pennsylvania State University Press.

Powell, G. Bingham, Jr. 2000. Elections as Instruments of Democracy: Majoritarian and Proportional Visions. New Haven: Yale University Press.

Powell, G. Bingham, and Guy D. Whitten. 1993. "A Cross-National Analysis of Economic Voting: Taking Account of the Political Context." American Journal of Political Science 37(2): 391-414.

Praino, Rodrigo, Daniel Stockemer, and Vincent G. Moscardelli. 2013. "The Lingering Effect of Scandals in Congressional Elections: Incumbents, Challengers, and Voters." Social Science Quarterly 94(4): 1045-1061.

Price Vincent and John Zaller. 1993. "Who Gets the News? Alternative Measures of News Reception and Their Implications for Research." Public Opinion Quarterly 57(2): 133-164.

Pye, Lucian W. 2006. Asian Power and Politics: The Cultural Dimensions of Authority. Cambridge: Harvard University Press.

Quah, Jon S. T. 2011. Curbing Corruption in Asian Countries: An Impossible Dream? Bingley: Emerald.

Rasmussen, Stig Hebbelstrup Rye. 2015. "Education or Personality Traits and Intelligence as Determinants of Political Knowledge?" Political Studies 64(4): 1036-1054.

Redlawsk, David P., and James A. McCann. 2005. "Popular Interpretations of 'Corruption' and Their Partisan Consequences." Political Behavior 27(3): 
261-283.

Reed, Steven. 1996. "Political Corruption in Japan.” International Social Science Journal 48(3): 395-405.

Sandholtz, Wayne, and William Koetzle. 2000. "Accounting for Corruption: Economic Structure, Democracy, and Trade." International Studies Quarterly 44(1): 31-50.

Saris, Willem E., and Paul M. Sniderman. 2004. Studies in Public Opinion: Attitudes, Nonattitudes, Measurement Error, and Change. Princeton, NJ: Princeton University Press.

Schedler, Andreas, Larry Diamond, and Marc F. Plattner. 1999. The Self Restraining State: Power and Accountability in New Democracies. Boulder: Lynn Rienner.

Seligson, Michael A. 2002. "The Impact of Corruption on Regime Legitimacy: A Comparative Study of Four Latin American Countries." Journal of Politics 64(2): 408-433.

Shin, Doh Chull. 2011. Confucianism and Democratization in East Asia. New York: Cambridge University Press.

Shleifer, Andrei, and Robert W. Vishny. 1993. "Corruption.” Quarterly Journal of Economics 108(3): 599-617.

Stockemer, Daniel, Bernadette LaMontagne, and Lyle Scruggs. 2013. "Bribes and Ballots: The Impact of Corruption on Voter Turnout in Democracies." International Political Science Review 34: 74-90.

Tavits, Margit. 2007. "Clarity of Responsibility and Corruption." American Journal of Political Science 51: 218-229.

Taylor, Michaell A. 2000. "Channeling frustrations: Institutions, economic fluctuations, and political behavior." European Journal of Political Research 38: 95-134.

Theobald, Robin. 1990. Corruption, Development, and Underdevelopment. Durham: Duke University Press.

Tillman, Erik R. 2008. "Economic judgments, party choice, and voter abstention in cross-national perspective.” Comparative Political Studies 41(9): 1290-1309.

Transparency International. Corruption Perceptions Index, various years. Accessed https://www.transparency.org/.

Treisman, Daniel. 2000. "The Causes of Corruption: A Cross-National Study." Journal of Public Economics 76(3): 399-457.

Tverdova, Yuliya V. 2011. "See No Evil: Heterogeneity in Public Perceptions of Corruption." Canadian Journal of Political Science 44: 1-25.

Uslaner, Eric M. 2008. Corruption, Inequality, and the Rule of Law: The Bulging Pocket Makes the Easy Life. New York: Cambridge University Press.

Uslaner, Eric M. 2013. "Trust and Corruption Revisited: How and Why Trust and Corruption Shape Each Other." Quality \& Quantity 47(6): 3603-3608. 
Wang, Ching-Hsing. 2015. "A Deeper Look at the Relationship between Political Knowledge and Political Participation: Evidence from Presidential and Legislative Elections in Taiwan." Asian Journal of Political Science 23(3): 397-419.

Wattenberg, Martin. P., Ian McAllister, and Anthony Salvanto. 2000. "How Voting is Like Taking a Sat Test: An Analysis of American Voter Rolloff." American Politics Research 28(2): 234-250.

Welch, Susan, and John Hibbing. 1997. "The Effects of Charges of Corruption on Voting Behavior in Congressional Elections, 1982-1990." Journal of Politics 59: 226-239.

Weschle, Simon. 2014. "Two Types of Economic Voting: How Economic Conditions Jointly Affect Vote Choice and Turnout." Electoral Studies 34: 39-53.

Winters, Matthew S., and Rebecca Weitz-Shapiro. 2013. "Lacking Information or Condoning Corruption: When Do Voters Support Corrupt Politicians?" Comparative Politics 45(4): 418-436.

Yadav, Vineeta. 2011. Political Parties, Business Groups, and Corruption in Developing Countries. New York: Oxford University Press.

You, Jong-sung, and Sanjeev Khagram. 2005. "A Comparative Study of Inequality and Corruption." American Sociological Review 70: 136-157.

Zaller John R. 1992. The Nature and Origins of Mass Opinion. Cambridge: Cambridge University Press.

Zechmeister, Elizabeth J., and Daniel Zizumbo-Colunga. 2013. "The Varying Political Toll of Concerns about Corruption in Good Versus Bad Economic Times.” Comparative Political Studies 46(10): 1190-1218. 